\title{
INDIGENOUS KNOWLEDGE AND SOCIO-ECONOMIC DEVELOPMENT OF A MALAYSIAN RURAL INDIGENOUS COMMUNITY
}

\author{
${ }^{1}$ Novel Lyndon, ${ }^{*}$ Mohd. Fuad Mat Jali, ${ }^{1}$ Rosniza Aznie Che Rose \\ *First Author \\ ${ }^{1}$ Center for Research in Development, Social and Environment, Faculty of Social \\ Sciences and Humanities, Universiti Kebangsaan Malaysia \\ (novel@ukm.edu.my) \\ DOI: https://doi.org/10.22452/jati.vol25no2.6
}

\begin{abstract}
Rural economic development strategy needs to be accomplished with distribution strategy which is aimed at development benefits targeted at lowincome groups by giving major focus on the role of local knowledge in the community development strategy. Therefore, the main objective of this study is to examine the role of local knowledge in the socio-economic development of the rural Iban community in Sarawak. This study employed the qualitative approach through in-depth interviews and focus group discussion data collection techniques. A total of 20 rural Iban were interviewed in this study. A nonprobability sampling technique through purposive sampling and snow-ball sampling was used. All data were analysed using the Nvivo software. Results reveal that local knowledge is the knowledge used as a response towards the inaccessibility to the use of technology, limited communication, and weak infrastructure facilities in their social environment. The role of local knowledge in this study refers to the added value and economic impact on their daily lives. Their local knowledge is integrative in nature, comprising aspects of language, social system, traditional practices, social interaction, rituals, and spirituality. The conclusion of the study is that the scientific knowledge that is obtained from the process of modernisation needs to be blended with the local knowledge and empowered to ensure that the survival of the rural Iban community in the agricultural sector as the main contributing sector towards their socio-economic development continues to remain relevant.
\end{abstract}

Keywords: local knowledge, community development, indigenous ethnic group, hill rice, modernisation 


\section{Introduction}

The philosophy and strategy of rural development in Sarawak can basically be divided into two phases of transformation (Madeline, 2004; Hew Sim, 2003; Lyndon, Selvadurai, Rose, \& Hong, 2015). The first transformation started in 1957 until 1994 and the second transformation began from 1994 until 2020 (Madeline, 2004). In the first transformation (1957-1994), the rural development policy was incomprehensive in terms of the infrastructure, lacking in attention to the environment, less focused on human development, and resulted in low rural community income, low minimum education level and the subsidy mentality syndrome (Madeline, 2004; Hew Sim, 2003). However, the agenda of the policy and strategy of rural development still did not stray from giving attention to the eradication of poverty through modernisation of the traditional sectors and incorporation of science and technology as well as the restructuring of the economic disparity among the ethnic groups (Chamhuri \& Norshamliza, 2006; Mohd. Yusof, Kasim Md., \& Gari, 2006).

In the second transformation phase (1994-2020), the philosophy and strategy of rural development still continues to be dominated by the modernisation approach as well as western dualism (Anuwar, Ishak, \& Nor Aini, 2006; Abdul Rahman, 2005; Hew Sim, 2003). This is because economic development is still considered as the ideal model in distributing the local community's social justice and that the development should be promoted by two institutions, namely the country and the market (Chamhuri, 2000). As a result, local knowledge of the local people and the traditional sector are said to require the injection of modernisation or added value from market demand (Chamhuri \& Rospidah, 2006). Thus, modern knowledge which is generated based on science and technology and western knowledge are used to modernise the production system and to teach the local people to be more effective and persistent (Chamhuri \& Nor Aini, 1996; Katiman \& Abd. Hamid, 1996). Nevertheless, both phases of transformation are still seen as inept, lacking, and insufficient in solving issues that arise among the Bumiputera (indigenous people) especially among the Iban ethnic group in terms of poverty, inequality in the distribution of income and employment, economic dependence, and quality of life (Minos, 2000; Campbell, Ghazali, \& Suffian Sahuri, 2016). The growing use of technology in the rural areas is also seen as incapable of providing huge benefits to the rural community because of its overpriced cost and weak infrastructure facilities. In fact, most low-income farmers have started to look for alternatives in non-agricultural fields to improve their socio-economic level. At the same time, changes in land productivity have led to the process of farmers' migration to farms and plantations as a result of the introduction of waged labour system 
(Chamhuri \& Norshamliza, 2006; Nor Aini, 2006; Abdullah, Othman, Jani, Bartholomew, Pesiu, \& Abdullah , 2020).

Therefore, economic development strategies based on scientific knowledge alone are expected to be incapable of lessening the problems of relative poverty or income gap among ethnic groups and social class as a result of the imbalance of job opportunity distribution. Several social scholars before this such as Sillitoe, Dixon, and Barr (2005) and Chambers (1992) have previously raised the problem and issue. Economic development strategies need to be accompanied by distribution strategies that target greater growth benefits for the low-income groups or the B40. In addition, the time has come for the government to pay serious and comprehensive attention to the knowledge of the local or indigenous people in their planning and implementation of development programmes. Indeed, this matter has been debated and discussed extensively and in-depth by previous social scholars such as Sillitoe (2000), Chambers 1995, Pieterse (2000) and Latouche (1993).

The local knowledge approach provides the best opportunity for the government especially the programme planners to learn and understand what is known and needed by the local community. This can subsequently help to improve the understanding of the planners on the actual situation or the reality faced by the local or indigenous people in finding resolutions on how development should be carried out and who would benefit or gain from the development (Antweiler, 1998). This step will subsequently provide solid or strong answers in designing efficient and effective community development strategies to address the issue of poverty which is the core problem that is continuously faced by the local or indigenous community (Chambers, 1992; Campbell et al., 2016). At the same time, such actions will help increase the empowerment of the poor through the attention or connection to their knowledge and practices of management (Chambers, 1992). This is because the blending of scientific knowledge with the local knowledge within the community and across the community will provide important components of global knowledge in issues of development. Simultaneously, helping the local or indigenous community based on their local knowledge enhances cross cultural knowledge and promotes cultural dimensions of development (Chambers, 1992; Sillitoe et al., 2005; Posey, 2004). Thus, the main objective of this study is to examine the role of local knowledge in the socio-economic development of the rural Iban community in Sarawak. 


\section{Literature Review}

\section{Concept of Local Knowledge in Community Development}

The failure of major development trends that are based on economic development and modernisation as well as market capitalism has created an escalating interest in combating poverty directly from the perspective of the local culture and knowledge system itself (Magni, 2017; Narayan, Chambers, Shah, \& Petesch, 2000). According to Briggs and Sharp (2004), the concept of local knowledge is the worldview of the local community and local needs in the effort to produce more effective and efficient development strategies. This is in line with Mannhein's (1952/1971) statement based on Ritzer who mentioned previously that knowledge is the worldview of the local community that is created based on culture, traditional values, and social norms (Ritzer, 2000). In contrast, the concept of local knowledge tends to use senses or the maturity of their thinking to describe their world based on the sharing of common sense (Giddens, 1984). In short, their local knowledge encompasses the social characteristics of the social actors' life including the social environment, the experiences in their daily lives and the realities of life in the world that have become the norm in their lives (Giddens, 1984).

Schutz (1973) has divided local knowledge into three meanings, namely the reciprocity of perspectives (the assumption that the object is known or knowable by everyone), the social origin of knowledge (the individual creates or builds a small part of their own knowledge and most exists in the knowledge stock that is shared and acquired through social interactions), and the social distribution of knowledge (people have different knowledge based on their position in the social structure). Based on the examination of the works of Durkheim, Lukes later called local knowledge as the first-order construct that contains the social reality of the social actors that encompasses the society, the structural components in the society such as the church and the state, and the morphological components in the society such as channels of communication, housing arrangements, population distribution, and morality (Lukes, 1972). In line with this view, Sillitoe et al. (2005) in their book on local knowledge research later named the relationship between social scientists and social actors as the continuum of knowledge that involves the knowledge of outsiders and insiders where the gradation of knowledge of the local people and outsiders relies on the origins of the community and formal education. The term and concept of local or indigenous knowledge is then referred to as local or indigenous people's understanding of indigenous resources or natural sources (Magni, 2017; Grenier, 1998). It is also used by social scientists to connect the understanding and culture of the local people to the scientific researchers and development practitioners 
(Agrawal, 1995). This is because local community knowledge is very different from global scientific knowledge as local community knowledge is shaped by culture, traditional values, and social structure (Pieterse, 2000; Campbell et al., 2016; Abdullah et al., 2020).

Additionally, the scientific approach is not seen as the best approach to solve or address the problems of development (Ellen \& Harris, 2000). Scientific knowledge refers to the knowledge generated from the western science knowledge and colonialism (Agrawal, 1995). In contrast, local knowledge is associated with knowledge of the village folks or rural people, traditional knowledge, local agricultural/farming knowledge, local technical knowledge, and traditional ecological/environmental knowledge (Sillitoe et al., 2005; Posey, 2004). Although there exists a multitude of labels and interpretations that is given to local knowledge, nearly all social scientists agree and share the same understanding and thought in that planning and implementation of community development programmes should be oriented towards the specific needs of the locals and the local knowledge of the community members themselves so that the programmes fulfil the inclinations of the community members (Posey, 2004; Sillitoe et al., 2005).

At the same time, such a move would enable the integration or incorporation of the scientific knowledge available to the planners with the local knowledge and worldview available to the community (Sillitoe et al., 2005;). This is the theoretical gap that is desired to be realised by local knowledge in its relationship with community development. The amalgamation or combination of the three aspects will then provide a strong platform and sphere in designing effective and efficient strategies to solve the issue of poverty which is the core problem that is continually faced by the local community (Chambers, 1994). Moreover, the main role of local knowledge in community development is to bridge the gap between technology that is established scientifically with local awareness and practices. This means that local knowledge should provide a twoway relationship between the needs and wants of the local people and the technocrats' scientific agenda (Sillitoe et al., 2005).

Additionally, the sharing of scientific knowledge or western knowledge with the local knowledge within the community and across the community will simultaneously make available important components of global knowledge in development issues and help to enhance cross-cultural understanding and promote cultural dimensions of development (Chambers, 1992). Indeed, by learning about the local knowledge and worldview of the local community, it will help the programme planners in understanding what is known and needed by the local community (Chambers, 1994) and this will simultaneously help to 
enhance the understanding of the planners about the actual situation or the social reality faced by the local people (Antweiler, 1998). Apart from that, it will also help to further empower the poor through the attention or connection to their management knowledge and practices (Sillitoe et al., 2005). This means that the local people and the poor will have the most prominent voice in the context of development because they are the people targeted to benefit from the development programmes to be carried out (Sillitoe et al., 2005). This process is not only used to find a resolution on how development should be carried out and who should gain or benefit from the development but also involves sharing of understanding about the issues at stake in deciding on a decision.

\section{An Overview of the Rural Development Policy in Malaysia}

Almost all government community development projects in the National Economic Policy (NEP) era (1970 to 1990) and the post-NEP era (1990-2020) tend to be based on the top-down planning approach instead of relying on initiatives that emerge from the bottom, that is from among the villagers itself (Rahmah Ismail \& Nasir, 2003; Rajah Rasiah, 2017). In this regard, King and Nazaruddin (1992) argued that rural development in Malaysia after the NEP era on the whole is mainly patterned based on the top-down approach and this has affected the contribution and effective involvement of community members. It is in contrast to the era of the National Development Policy which started in 1990 where the main focus of its development policy and strategy is to create a socio-economic environment to achieve national unity through economic redistribution programmes regardless of race so that restructuring of society can be achieved (Sarmila, Zaimah, Lyndon, Hussain, \& Awang, 2015). The implementation of the National Urbanisation Policy (NUP) also shows the government's efforts to create a more optimal development pattern between the goals of economic growth and equitable distribution (Rajah Rasiah, 2017).

There are four main aspects emphasised in the NEP, namely: i) ensuring a balanced development for the first sector of the economy to enable growth to be more equitable and complement and help each other; ii) reducing and ultimately eliminating the social and economic imbalances of the country to encourage the sharing of benefits derived from growth fairly and equitably for all Malaysians; iii) promoting and strengthening national integration by reducing the wide gap in economic development between states and regions; and iv) developing a progressive society whose well-being is enjoyed by all citizens while having a positive spiritual attitude and values (Uchoh, Gapor, \& Lyndon, 2014). Based on the four main goals of the NEP, it is clear that there is a very significant shift in the paradigm of Malaysia's economic development, which in 
turn has seen most of its development strategies setting aside the laissez-faire policy. In this regard, some local scholars such as Madeline (2004), Lyndon et al. (2015) and Uchoh et al. (2014) consider the NUP as one of the alternative development strategies. This is because the NUP's main focus is on the impact of development on certain groups based on cultural criteria and ethnicity rather than based on economic function. Apart from that, the main focus of its rural development strategy is on developing equity distribution, poverty eradication, provision of basic facilities, use of appropriate technology and decentralisation programmes (Madeline, 2004). In addition, human-centred development policies and strategies, human safety, and the sustainability of human development began to be placed at the core and became an important pulse in the NUP, and these subsequently became a key approach in Vision 2020 (Madeline, 2004).

In 2019, the Rural Development Policy for the period up to 2030 was launched where the main goal is to create a rural community that is proactive in developing the local community (Kementerian Luar Bandar Malaysia, 2019). The main agenda of this policy is to help rural communities, especially those of lowincome, to be better prepared to face the technological advances of the 4th Industrial Revolution era, particularly in the agriculture and livestock sector. In short, the main goal of this policy is to produce a prosperous, inclusive, sustainable, and holistic rural area in order to reduce rural to urban migration. Therefore, in this policy, one of the main focuses that is given attention is providing employment opportunities by attracting more investors to invest in rural areas in either the plantation or industrial sector. Various infrastructure and accessibility to investor-friendly social facilities that are comparable to urban areas are to be built in rural areas. Rural areas targeted for development will offer employment and business opportunities that can increase the income of the rural population. Those living in rural areas will also enjoy ample opportunities to build human capital capacity, healthy and safe living, and receive services in governance which are easily accessed, comparable to those living in the city. Through this Rural Development Policy, the government under the Ministry of Rural and Regional Development has a high commitment to close and eliminate the quality gap between urban and rural areas. At the same time, several community development programmes are also implemented to create economic opportunities and a conducive social environment to attract the rural population, especially the youths to continue living in the rural areas (Kementerian Luar Bandar Malaysia, 2019). In addition, the government also intends to attract some of the population and investors in the city to migrate to rural areas to increase the economic capacity in the rural areas. 


\section{Methodology}

\section{Description of the Study Area}

This research was carried out in Sungai Lemanak, in the Small District of Engkilili, Sarawak. This area was chosen because the farmers here still use local knowledge as the basis in their rice planting activities. The population in the Small District of Engkilili totalled 16,719, of which the majority is made up of the Iban people at 14,674 , the Chinese (1,119), the Malays (432), and the Bidayuh (79) while the rest are from the other indigenous ethnic groups (Sarawak, 2018). There are 400 longhouses in the Sungai Lemanak area, most of which are inhabited by the Iban community.

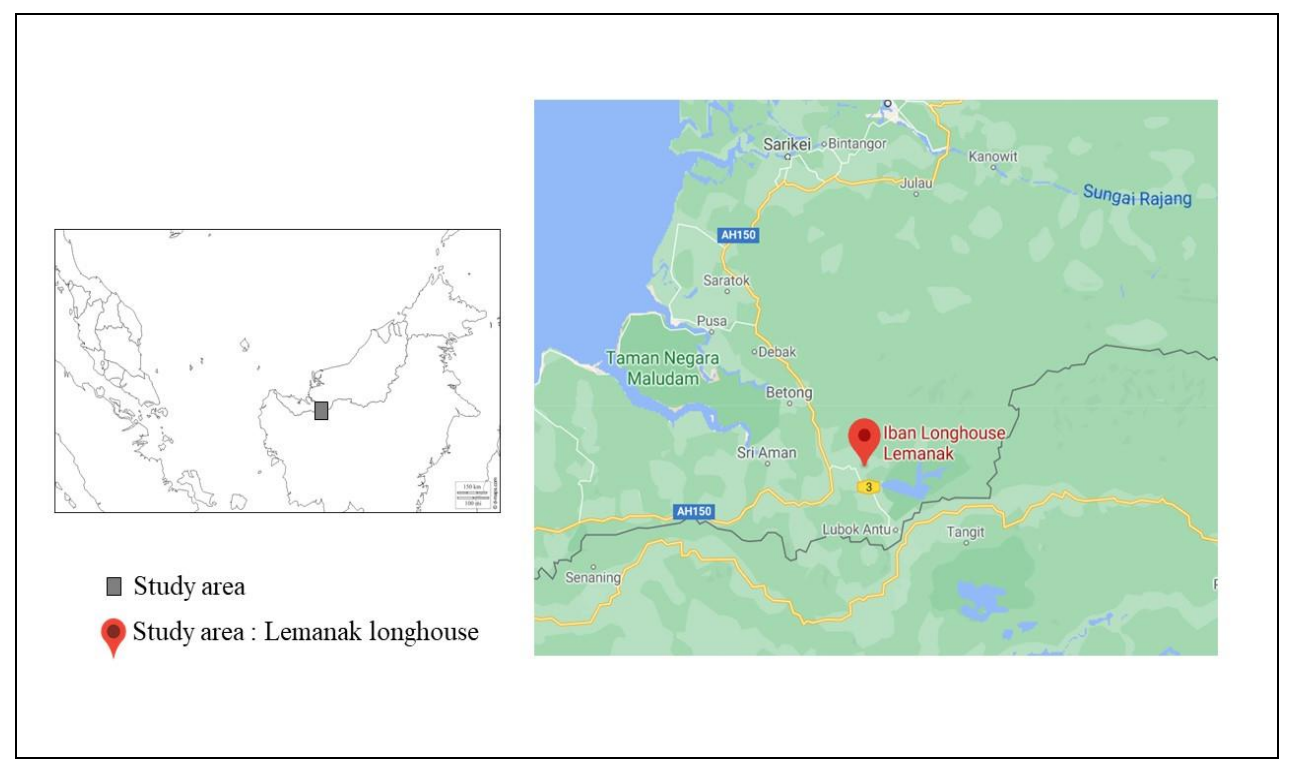

Figure 1: Research location where the study was conducted (Source: Google Map, 2020)

In terms of the administrative aspect, Sungai Lemanak is under the administration of the Sri Aman Division which is headed by a Resident. However, to make the administration efficient, Sri Aman Division is split into small districts which are administered by a District Officer. For administrative purpose, Sungai Lemanak area is placed under the administration of Lubok Antu District Council (MDLA) which is located in Engkilili Small District (Sarawak, 2018). Meanwhile, MDLA is also assisted by the Penghulu (headman) in administering the people's settlement areas where they are tasked in matters of longhouse customs such as marriages, disputes, customary land, and others. The 
duties of the Penghulu are also assisted by the Tuai Rumah (head of an Iban longhouse) who heads each longhouse community in Sungai Lemanak. Additionally, each longhouse has a committee known as the Village Welfare and Security Committee (Jawatankuasa Kebajikan dan Keselamatan Kampung or JKKK for short) which is chaired by the Tuai Rumah who receives the support of the majority of the longhouse inhabitants.

Additionally, in relation to the economic aspect, the Iban community in Sungai Lemanak relies on agricultural economic activities in continuing their livelihood. Among their main agricultural activities is hill rice (dry paddy) cultivation which is inherited for generations from their ancestors. However, the scale of their hill rice cultivation is small in that it is just enough for their own use. The Iban community in Sungai Lemanak also cultivates oil palm, black pepper, cocoa, and rubber; nevertheless, these are carried out on a small and medium scale only. This is because of the problems of small land area, poor road network, and inaccessibility to processing plants or factories that are located at a distance from their farms. Apart from that, the Iban community settlement area in Sungai Lemanak also has very limited basic facilities. There are two alternatives that can be used to connect this area, namely through land and river transportation. The basic facilities available in this area consist of three primary schools and two village health clinics. Supply of clean water is obtained from the hills and electricity is yet to be fully connected; the people here still rely on generators to produce electricity for their home use.

\section{Research Method}

This study used the phenomenology approach based on idealist ontology and constructionist epistemology. The main focus in the phenomenology approach is to elaborate and describe the experience and knowledge of the social actors of a concept based on their worldview rather than the views and perspective of the researcher. In this study, the interviews conducted between the researcher and the informants were focused on the meaning of education according to the informants' views and how this meaning of education helps them to carry out the social mobility process that is encircled by the community's social structure. Most of the interviews carried out took between two to three hours; there were also some which took much longer. The study's data were collected using nonprobability sampling technique, namely purposive sampling and snowball sampling.

A total of 20 rural ethnic Iban people in Sungai Lemanak, which is located in the Small District of Engkilili, were chosen for this study based on the established criteria. Among them, the informants must have experienced social 
mobility and live in the rural area. The informants were rice farmers and rice cultivation was their main job. Nevertheless, level of education and type of employment were not taken into consideration as the main requirement or condition to be selected as this study's informant. Data were collected through the method of in-depth interview. Additionally, an interview guide was constructed to help with the interview process. The study's sampling size was achieved through continuous support towards the measurement or criteria of theoretical saturation. Theoretical saturation occurs when no new themes or categories emerge and no relevant data that can discuss or act on the existing categories are available. All the interviews were transcribed and formatted for inclusion in the Nvivo database and were then used to create categories and to index the data.

\section{Findings and Discussions}

Cultivation of hill rice (dry paddy) is often associated with the rural Iban community's socio-economic development. Rice is seen as the identity, the symbol of life, the connection with the ancestors, and the symbol of social mobility; additionally, they also believe that there is spirit in rice (Freeman, 1955; Sandin, 1967; Uchoh et al., 2014; Campbell et al., 2016).

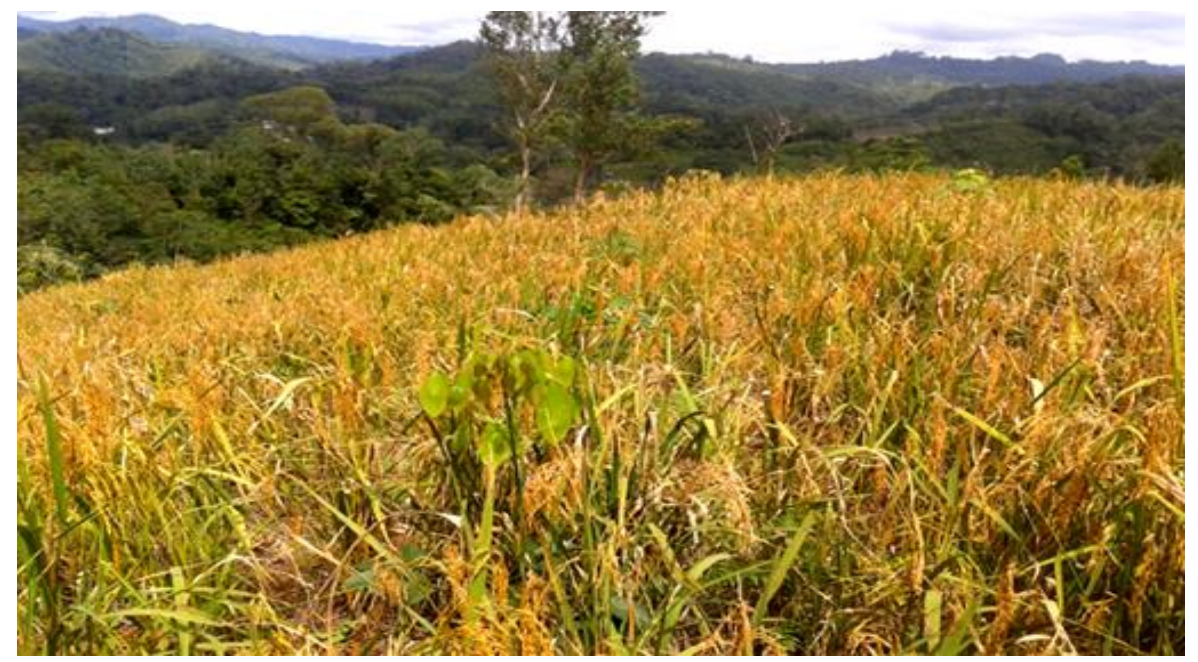

Figure 2: Bountiful hill rice that is ripe and fully grown and ready for harvesting. (Source: Novel Lyndon)

The Iban community uses their indigenous/local knowledge and skills developed as a result of their interaction with the natural environment to interact with the rice that they grow. Their local knowledge provides added value and economic 
impact on their daily life. Their local knowledge is characteristically integrative, encompassing aspects of language, social system, traditional practices, social interactions, rituals, and spirituality. On the basis of that principle, the Iban ethnic group has their own way of cultivating hill rice crops which are their main source of living. There are five main processes that the Iban farmers have to undergo in planting the hill rice and they consist of i) selecting the hill rice cultivation area; ii) clearing the forest and the hill rice cultivation site; iii) burning the hill rice cultivation site; iv) selecting the hill rice seeds; and lastly v) planting the hill rice. However, the conduct of this cultivation process is facing various challenges today and thus, it is important for them to master the knowledge of hill rice cultivation that has been passed down from their ancestors. Previously, before the process of modernisation and before the Iban community converted to Christianity, statues were usually carved and made as part of the hill rice cultivation ritual that is known as mali umai or ngemali umai or nambai umai. Nevertheless, the use of statues in rice cultivation activities is still being practiced by a small number of Iban community, and it is sometimes interlaced with the use of modern technology.

\section{Selection of Hill Rice Cultivation Area}

The first phase that must be carried out by the Iban community before they begin the process of hill rice cultivation is to identify a suitable area for planting the hill rice. This is really important as it would ensure that the hill rice planted in the area flourishes and grows well and produces abundant yield for the daily use of the family. The process of identifying the area for hill rice cultivation is carried out after the Iban community brings to a close the Gawai Dayak festival which is known as Ngiling Bidai at the end of June. To identify fertile land, the Iban community will choose a forest area that has yet to be explored or more known as virgin forest. In this regard, the Iban community believes that such a forest has natural soil nutrients that would make the land fertile and this will further increase the growth of their hill rice. These soil nutrients are formed from the interaction or relationship between the living things and non-living things in the natural environment or more known as the ecosystem. This was stated by R3 who mentioned looking for virgin land which is still not fully explored and still has an abundance of wildlife living there. R3 mentioned that the land should be examined based on the distribution of earthworms' manure or castings. If there are a lot of earthworms' castings, the soil is thus very fertile and very suitable for rice cultivation.

Additionally, the Iban community also looks at the new moon in determining the most suitable time to start the hill rice cultivation activity. For 
the Iban community, they will start looking for a place to cultivate the hill rice when the new moon appears for the first time after the Gawai festival comes to an end. The next day, all the hill rice farmers will carry out the miring ceremony at the place or location they feel most suitable for cultivating the hill rice for that year. If they do not get any bad dreams during the night after the miring ceremony, they can therefore clear the forest the next day. This was elaborated in great lengths by R1, R2, R5, R6 and R8 who mentioned that the knowledge of the elders should be abided and carried out to ensure the rice cultivated produces abundant yield. The miring ceremony has to be performed beforehand as an indication or sign that their hill rice cultivation activity has been blessed by Gods known as Sengalang Burung, Sempulang Gana and Semerugah.

\section{Clearing the Forest and the Cultivation Site of Hill Rice}

After a suitable area for the cultivation of hill rice has been identified, the farmers then begin to clear the forest area. However, prior to beginning the activity of clearing the forest area, a ceremony to ask for blessings from the Land God known as Semerugah is performed by touching the soil. This ceremony is carried out so that the place is always protected from any disturbance and threats from animals or pests. The items needed to perform the ceremony are a chicken, air tuak (rice wine), sirih (betel leaves), pinang (areca or betel nut), and rendai (puffed rice) which are intended as food offerings to the Semerugah. This was stated by R4, R8 and R9 who mentioned that several incantations will be read, and the ritualistic ceremony will be performed to ask for protection from the God of Semerugah. This is an example of the spell: "Tanah yang berbau kurang menyenangkan, diminta untuk dilempar oleh orang, dialihkan orang, tanah yang subur, yang berlemak untuk kami menanam padi, tempat kami bercucuk tanam, supaya kami mendapat padi, dapat nasi, dapat air" (Soil that smells a bit unpleasant, asked to be thrown by the people, tilled by the people, fertile soil that is full of nutrients for us to plant rice, a place for us to tillage, so that we can get paddy, get rice, get water).

During the phase of clearing the hill rice cultivation site, there are some taboos that need to be followed by the farmers. For example, if they hear the sound of birds' calling or that of other animals while on their way to the forest area that they are clearing, it is compulsory for them to immediately return or go back to the longhouse. According to the traditional beliefs of the Iban community, those bird sounds or calls give them warning that something bad is going to happen to them if they continue with their journey to the hill rice cultivation site or if they continue with the clearing work on the hill rice cultivation area. Among the bad things that may occur if they ignore the calls of 
the birds are hardship, death in the family, accidents such as wounds that may even cause deaths, and their life becoming poorer. According to R5, bird sounds or calls that should be obeyed are those made by the Ketupung, Jaluh, Pangkas and Embuas birds. If they hear the calls of these birds, it is compulsory for the farmers not to continue with the clearing activity of the hill rice cultivation site. This is because if the activity were to be continued, it would endanger or bring disaster to the farmers. They believe that even the family members of the farmers can become poor because the farmers did not get the blessings of their ancestors and did not respect the spirit that is within the rice. The following is the statement of R5 on the matter: "If the sound of birds calling or chirping is heard or the sound of other birds such as the Ketupung, Jaluh, Pangkas, Embuas, the farmer must thus return home and stop the cutting or slashing. This is to avoid from having to face prolonged problem of poverty up to several generations".

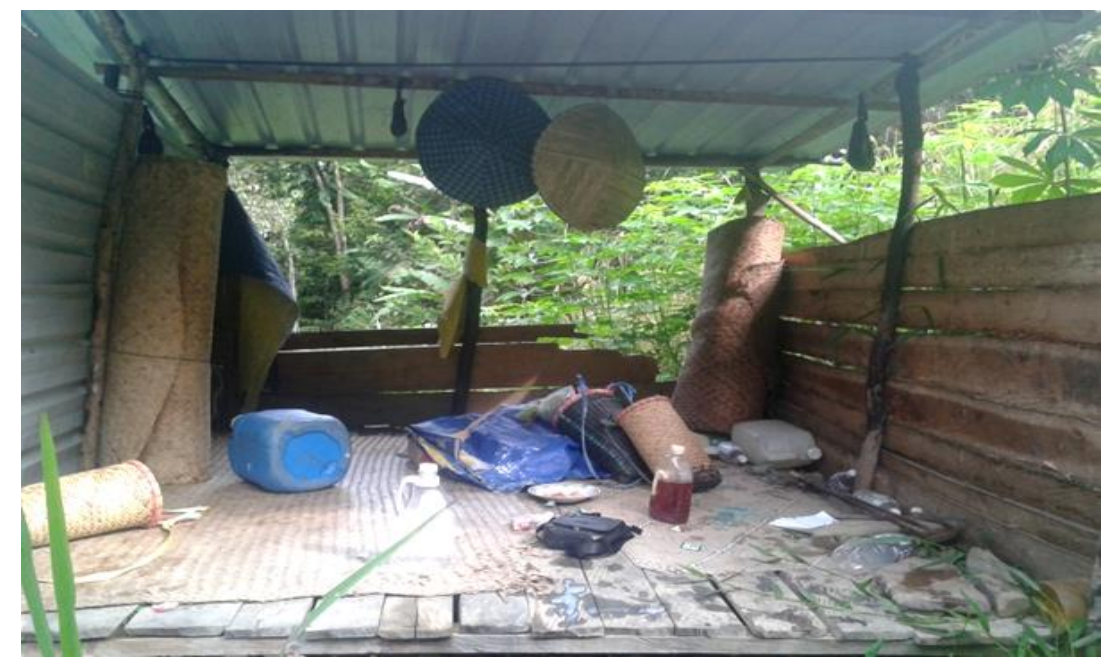

Figure 3: Hut which is erected as a place of shelter throughout the process of paddy cultivation (Source: Novel Lyndon))

In the process of clearing the hill rice cultivation site, the Iban community also has their own tools or equipment to help them in working the area. Among them are machetes, axes, and several other modern tools such as chainsaw and weed killer which have become the main tools utilised to cut down trees, kill weeds, cut branches, and many others. Labour often comprises family members and is sometimes assisted by close friends. The time taken to clear the hill rice cultivation site is between three to four weeks depending on the land size used as the site for rice cultivation. 


\section{Burning the Hill Rice Cultivation Site}

After the hill rice cultivation site has already been cleared, the farmers will leave the felled trees as well as the cut grass under the sun. This process is commonly known as the drying process. The purpose is to ensure that the wood will be easily burnt and scorched by the fire. This phase is entirely dependent on the local weather where it requires hot weather to accelerate the process of drying the cut trees that are left out in the sun. Nevertheless, the hill rice farmers do not dare burn the site if there is prolonged drought because they worry that the fire will spread and burn the nearby cultivation sites owned by other farmers. The following is the statement made by R6: "During the process of burning the hill rice cultivation site, we definitely depend on the weather; if it is the rainy season, it will take quite a while to dry the piles of wood, if it is the dry season, the time taken is not too long. Based on the previous elders, they did ask for dry weather from God if the days were always overcast and the sun did not shine. The ceremony is generally carried out at the cultivation site and several items used for the rituals of the ceremony such as chicken, eggs, incense and chicken blood will be used throughout the conduct of the ceremony".

During the process of burning the hill rice cultivation site, the Iban community helps each other out in controlling the fire from spreading to other places such as the pepper farm, the rubber plantation, or fruit orchard of others. This matter is strongly emphasised as it can lead to fights among the inhabitants of the longhouse should the fire from the rice cultivation site spread to the site of others. To avoid this, each individual who comes to help will be stationed around the rice cultivation site supplied with a water sprinkler that is filled with water beforehand to extinguish the fire should it spread to other areas. Not only that, the process of burning the rice cultivation site also needs to be carried out during an appropriate time period. Normally, the Iban community chooses the mid-morning time that is between 9 to 11 in the morning to burn the rice cultivation site. There are also some who choose the late afternoon between 3 to 5 for the purpose. This action is taken because at these times, the piles of wood and the grass left to dry would have completely dried; additionally, the weather would not be too hot at these hours, and this would facilitate their task of controlling the fire from spreading to other areas. Apart from that, the Iban community also pays attention to the movement of the wind while burning the rice cultivation site. In this case, the person in-charge of the burning will burn the piles of wood at the edges of the cultivation site first before the fire spreads to other piles of wood following the direction of the wind. This was explained by R7 who mentioned that they "follow the direction of the wind when burning. If not, it would be very difficult for us to control the fire. It is even more so if at that 
time the wind is strong. That is why we must stick to the right time when burning the rice cultivation site. Must follow the wind direction. The ideal time is around 9 to 10 in the morning. In the afternoon, around 3 to 5 p.m. This is because the wind would have died down then".

Nevertheless, if the hill rice cultivation site does not completely burn as a result of uncertain weather, the farmers would therefore need to pile the unburnt wood again in a specific area. This is done to ensure that the hill rice cultivation site is completely cleared. At the same time, it is also carried out to facilitate the process of planting and spraying of fertilisers. According to R9, "the piled wood is known as tugung panduk. The pile will be burnt again until it is completely reduced to ashes. The burnt wood will later become fertilisers to the rice planted. Interestingly, any side crops such as vegetables that are planted in the tugung panduk area will grow well and need not be given any fertilisers. Rice planted near the area will also grow well and produce a lot of yield. Hill rice yield that is abundant and enough for the family members' use will help the head of the family to work on other commercial crops such as pepper, rubber, and oil palm. At the same time, this would make it easy for them to earn side income by working in small towns or big cities". This description clearly shows that the rice crop is not merely their main staple food but also a tool for the Iban community to enhance their social mobility.

\section{Selection of Hill Rice Seeds}

The hill rice seeds selected for cultivation are seeds inherited from the earlier generations of the Iban community's ancestors and are passed down until the present day. To ensure that the seeds are always available and sustainable, the Iban community would never process the entire paddy into rice. On the other hand, they would keep a little of each type of rice that they own to be used as seeds and these would be kept properly until the hill rice planting season arrives. Among these are the Padi Seru, Padi Selasih, Padi Entulang, Padi Tarat and Padi Pulut (please refer to Table 1). Each of these rice seeds has its own unique characteristics and requires local knowledge for their identification process.

Table 1: List of Seeds Planted

\begin{tabular}{|c|l|l|}
\hline No & \multicolumn{1}{|c|}{ Name of Rice } & \multicolumn{1}{c|}{ Features } \\
\hline 1 & Padi Seru & Has lines on its seeds \\
\hline 2 & Padi Selasih & Blackish in colour \\
\hline 3 & Padi Entulang & Reddish in colour \\
\hline 4 & Padi Tarat & White in colour \\
\hline
\end{tabular}


Additionally, the hill rice seeds grown by the Iban community are also obtained from various parties. This was stated by $\mathrm{R} 9$ who mentioned that the seeds grown by him are inherited from his ancestors and are also obtained from close family members. Subsequently, R10 mentioned that the seeds obtained by him and his wife are from the gifts or dowry given by family members during their wedding ceremony. In other words, each Iban in the community that gets married will bring supplies of hill rice seeds from their respective families as the foundation in building a new family.

\section{Planting the Hill Rice}

The process of planting the hill rice by the Iban community is carried out after all the preparations such as seed preparation have been fully prepared. Each type of seeds will be placed in a gunny sack in the required quantity. On top of that, other preparations such as building the dampa or a small hut also need to be performed first so that there is a place for shelter when planting the rice later. Additionally, tools for planting the rice also need to be prepared earlier; one example is the tugal which is a tool used to make or poke a hole in the soil to place the rice seeds. The best time to plant the rice seeds is determined by looking at the stars in the night sky and this ritual is performed by the oldest person in the longhouse. The oldest person is chosen because they have a lot of experience in predicting the most suitable time. Determining the most suitable time is crucial to ensure that the rice cultivated will produce a lot of yield and will not be disturbed or attacked by pests. According to R5, the ideal time for beginning the hill rice planting activity is identified when there are a lot of stars distributed in the sky and the bintang tiga (the Orion) is in the sky. He mentioned that before planting the rice, they will all go out to the covered verandah or ruai of the longhouse to look at the distribution of stars in the sky by focusing on the appearance of the bintang tiga. If the bintang tiga is not seen and the distribution of the stars in the sky is not that plenty, the process of rice planting will thus be postponed. There are also some in the Iban community who are guided by the moon which acts as an indicator in determining suitability of time to plant the hill rice. This was mentioned by $\mathrm{R} 3$ who stated that he uses the moon as a guide in determining the time to plant the hill rice.

Typically, once the best time to plant the hill rice has been known, the inhabitants of the longhouse will then gather to discuss the beduruk activity or the communal work (gotong royong) to plant the hill rice. Normally, this communal work activity is participated by more than two families and involves close family members. After reaching a consensus, the families involved in the beduruk will establish a turn to plant the rice among those involved. Usually, the 
womenfolk will place the seeds in the holes that have been dug by the men. The miring ceremony will be performed to ensure that the rice planted in the area flourishes, is not disturbed by pests, has the 'consent' of other living creatures, and is protected by their ancestors. There are also some taboos that the Iban community has to take heed of while determining the beduruk activity among the members involved. This was stated by R2 who mentioned that among the taboos is that the beduruk activity must follow the sequence that has been agreed upon earlier to avoid the wrath of their ancestors. Once the process of hill rice planting and the duruk turn are completed, the inhabitants of the longhouse will perform the symbolic ritual known as bebasu arang. In order to perform this ritualistic activity, each family that has finished planting the hill rice will bring some ash from their hill rice cultivation site to the longhouse. Then at night, each individual involved will wash their hands using water prepared in a bowl during the nugal (dibbling) session. The next day, they will bring the water to the site of their hill rice cultivation to be poured over the area.

\section{Conclusion and Recommendations}

Two conclusions can be drawn from this study. The first conclusion is that local or indigenous knowledge is an essential knowledge for the local community in adapting to the changes happening in their social environment. This is because the community's environment is constantly changing in line with the changing times that could not be curbed by the community itself. The changes happening in the structure of a community will also indirectly influence other structures where they would occur simultaneously or otherwise. In this regard, the local knowledge on hill rice cultivation possessed by the Iban community is also not exempted from going through such change. Therefore, elucidation on this matter should be viewed from various perspectives, particularly from the cultural perspective in order to understand the social reality faced by the Iban community today. A culture is formed by the community itself based on the acceptance of all its members. The culture developed will subsequently become the identity of the community which distinguishes them from other communities. A community forms or develops their culture because it has its own unique function. Giddens (1984) and Abdullah, Othman, Edo, and Jani (2019) for example stated that all cultural activities are actually intended to satisfy a social network from a number of human needs that are connected to the rest of their life.

The second conclusion is that there are still farmers of the Iban community who maintain the culture of hill rice cultivation inherited from their previous generation of ancestors. This is because the Iban community believes 
that each of the local knowledge used in their agricultural activity has its own function in maintaining their relationship with the rice spirit. On this basis, the main role of local or indigenous knowledge in community development is to bridge the gap between scientifically established technologies and local awareness and practices. This means that local knowledge should provide a two-way relationship between the needs and wants of the local people and the technocrats' scientific agenda (Sillitoe et al., 2005; Uchoh et al., 2014; Abdullah et al., 2020). Furthermore, communities are always evolving in their lives to form a community that is far better than previously. Additionally, communities will always ensure that their social structure is flexible in nature so that it is adaptable to the passage of time and the process of modernisation. This coincides with Gidden's (1984) view where he states that modernity is a Juggernaut, an enormous forceful power that moves across all aspects of social life. For example, in the cultivation of hill rice, the Iban community has had to adapt themselves to scientific knowledge in order to increase the production of their rice. At the same time, this scientific knowledge is then blended with the local knowledge they inherited from their ancestors. The combination of both knowledge in the end has successfully helped in ensuring the continuity and relevance of their socioeconomic development that is based on the agricultural sector. The conclusion derived from this study therefore supports the serious need for the government to take into account the knowledge of the local community when channelling assistance and advisory services in hill rice cultivation activities. This is to ensure that the assistance provided through the distribution of fertilisers, seeds and pesticides meet the needs and wants of the hill farmers and support them in improving their socio-economic development.

\section{Acknowledgements}

The researcher would like to express his deepest gratitude to Universiti Kebangsaan Malaysia for financing this study through the MPOB-UKM Endowment Chair grant (project code: EP-2017-034) which has enabled this research to be conducted efficiently and successfully.

\section{References}

Abdullah, M.F., Othman, A., Jani, R., Bartholomew, C.V., Pesiu, E,. \& Abdullah, M. T. (2020). Traditional knowledge and the uses of natural resources by the resettlement of indigenous people in Malaysia. JATI -Journal of Southeast Asian Studies, 25(1), 168-190. 
Abdullah, M. F., Othman, A., Edo, J., \& Jani, R. (2019). Multidimensional poverty index of marginalized Orang Asli in Terengganu, Malaysia. Pertanika Journal of Social Sciences \& Humanities, 27(2),1241-1259.

Abdul Rahman, E. (2005). Development and well-being. Bangi: Penerbit Universiti Kebangsaan Malaysia.

Agrawal, A. (1995). Indigenous and scientific knowledge: some critical comments. Indigenous Knowledge and Development Monitor, 3(3), 1-12

Antweiler, C. (1998). Local knowledge and local knowing: an anthropological analysis of contested cultural products in the context of development. Anthropos, 93, 469-494.

Anuwar, A., Ishak, Y., \& Nor Aini, I. (2006). Proses industrialisasi dan pembangunan ekonomi Malaysia. In Ishak Yussof, Nor Aini Idris, \& Basri Abdul Talib (Eds.), Ekonomi Malaysia ke arah pascaindustri (pp. 3553). Bangi: Penerbit Universiti Kebangsaan Malaysia.

Barrett, Robert J. (1993). Performance, Effectiveness and the Iban Manang', in the Seen andthe Unseen: Shamanism, Mediumship and Possession in Borneo, Robert L. Winzeler, ed. Borneo Research Council Monograph 2.

Briggs, J., \& Sharp, J. (2004). Indigenous knowledges and development: A postcolonial caution. Third World Quaterly, 24(44), 661-676.

Campbell, Y. M., Ghazali, K., \& Suffian Sahuri, S. S. (2016). Preserving indigenous knowledge through folk narratives: Podi and Ngoyu. JATIJournal of Southeast Asian Studies, 21(12), 203-219.

Chambers, R. (1992). Rural appraisal: Rapid, relaxed and participatory. ID Discussion Paper, 311, 1-60.

Chambers, R. (1994). The origins and practice of participatory rural appraisal. World Development, 22(7), 953-969.

Chamhuri, S. (2000). Poverty focused development programs: Reaping the benefits of globalisation? Borneo Review, 11(1).

Chamhuri, S., \& Nor Aini, I. (1996). Pertumbuhan dan kemiskinan: satu sorotan. In S. Chamhuri, \& I. Nor Aini (Eds.), Kemiskinan dalam arus pembangunan ekonomi Malaysia (pp. 21-39). Bangi: Penerbit Universiti Kebangsaan Malaysia.

Chamhuri, S., \& Norshamliza, S. (2006). Dasar, strategi dan program pembasmian kemiskinan: Penilaian keberkesanan, isu dan masalah. In Ishak Yussof, Nor Aini Idris, \& Basri Abdul Talib (Eds.), Ekonomi Malaysia ke arah pascaindustri (pp. 152-175). Bangi: Penerbit Universiti Kebangsaan Malaysia.

Chamhuri, S., \& Rospidah, G. (2006). Pembangunan mapan dan proses perindustrian. In Ishak Yussof, Nor Aini Idris, \& Basri Abdul Talib (Eds.), 
Ekonomi Malaysia ke arah pascaindustri (pp. 92-114). Bangi: Penerbit Universiti Kebangsaan Malaysia.

Ellen, R., \& Harris, H. (2000). Introduction. In R. Ellen, P. Parkes, \& A. Bicker (Eds.), Indigenous environmental knowledge and its transformations (pp. 1-33). Amsterdam: Harwood Academic Publishers.

Freeman, J. D. (1955). Iban agriculture: A report on the shifting cultivation of hill rice by the Iban of Sarawak. London: Her Majesty's Stationery Office.

Giddens, A. (1984). The constitution of society: outline of the theory of structuration. Berkeley: University of California Press.

Grenier, L. (1998). Working with indigenous knowledge: a guide for researchers. Ottawa: IDRC.

Hew Sim, C. (2003). Women workers, migration and family in Sarawak. London, New York: Routledge Curzon.

Katiman, R., \& Abd. Hamid, A. (1996). Keperluan asas, pembangunan rakyat termiskin dan pusat perkhidmatan desa: Pengajaran dari Hulu Terengganu. In S. Chamhuri, \& I. Nor Aini (Eds.), Kemiskinan dalam arus pembangunan ekonomi Malaysia (pp. 238-259). Bangi: Penerbit Universiti Kebangsaan Malaysia

Kementerian Luar Bandar Malaysia. (2019). Dasar pembangunan luar bandar Malaysia [Malaysian rural development policy). Retrieved from https://www.rurallink.gov.my/

King, V. T., \& Nazaruddin, M. J. (1992). Isu-isu pembangunan luar bandar di Malaysia. Kuala Lumpur: Dewan Bahasa dan Pustaka.

Latouche, S. (1993). In the wake of the affluent society: An exploration of post development. London: Zed.

Lukes, S. (1972). Emile Durkheim: His life and work. New York: Harper dan Row.

Lyndon, N, Selvadurai, S., Rose, R. A. C., Hong, H. S. (2015). Cattle marketing social network among the rural native community, Sarawak, Malaysia: A qualitative research. Mediterranean Journal of Social Sciences, 6(5), 269-277.

Madeline, B. (2004). Towards the National Vision Policy: Review of the economic policy and New Development Policy among the Bumiputera communities in Sarawak. Journal of Malaysia Studies, XXI(1), 211-256.

Magni, G. (2017). Indigenous knowledge and implications for the sustainable development agenda. European Journal of Education, Research Development and Policy, 2(11), 22-38.

Minos, P. (2000). The future of the Dayak Bidayuhs in Malaysia. Kuching: Lynch Media and Services.

Mohd. Yusof, K., Kasim Md., M., \& Gari, I. (2006). Isu kemiskinan bandar: kes negeri Sabah. In Ishak Yussof, Nor Aini Idris, \& Basri Abdul Talib (Eds.), 
Ekonomi Malaysia ke arah pascaindustri (pp. 176-192). Bangi: Penerbit Universiti Kebangsaan Malaysia.

Narayan, D., Chambers, R., Shah, M. K., \& Petesch, P. (2000). Voices of the poor crying out for change. Oxford: Oxford University Press.

Nor Aini, I. (2006). Isu dan masalah kemiskinan di Malaysia. In Ishak Yussof, Nor Aini Idris, \& Basri Abdul Talib (Eds.), Ekonomi Malaysia ke arah Pascaindustri (pp. 134-151). Bangi: Penerbit Universiti Kebangsaan Malaysia.

Pieterse, N. J. (2000). After post-development. Third World Quarterly, 21(2), 175 191.

Posey, D. A. (2004). Indigenous knowledge and ethics: A Darrell Posey reader. New York: Routledge.

Rahmah Ismail, \& Nasir, M. S. (2003). Perancangan pembangunan. Dalam Rahmah Ismail, \& Mohd. Shukri Hajinoor (Eds). Dimensi ekonomi pembangunan teori dan realiti. Bangi: Penerbit Universiti Kebangsaan Malaysia.

Rajah Rasiah. (2017). Book Review: Charting the economy: Early 20th century Malaya and contemporary Malaysian contrasts. Malaysian Journal of Economic Studies, 54(2), 315-316.

Ritzer, G. (2000). Classical sociological theory. New York: McGraw-Hill.

Sandin, B. (1967). The Sea Dayaks of Borneo before White Rajah rule. London: Macmillan.

Sarmila, M. S., Zaimah, R., Lyndon, N., Hussain, M. Y., \& Awang, A. H. (2015). Local community economic wellbeing through CSR project. Mediterranean Journal of Social Sciences, 6(4S3), 79-87.

Schutz, A. (1973). Collected papers 1: The problem of social reality. The Hague: Martinus Nijohoff.

Sillitoe, P. (2000). Let them eat cake, indigenous knowledge, science and the poorest of the poor. Anthropology Today, 16(6), 3-7.

Sillitoe, P., Dixon, P., \& Barr, J. (2005). Indigenous knowledge inquiries: A methodologies manual for development. Dhaka: University Press.

Uchoh, D. U., Gapor, S. A., Lyndon, N. (2014). Religion and cultural change in paddy farming among native in Sarawak, Malaysia. Social Sciences, 9(5): 349-353 